\title{
Relationship between Cell Morphology and Intracellular Potassium Concentration in Candida albicans
}

\author{
Hiroshi Watanabe, Masayuki Azuma, Koichi Igarashi, Hiroshi Ooshima
}

Received: February 15, 2006 / Accepted: May 10, 2006

(C) Japan Antibiotics Research Association

\begin{abstract}
Previously we reported that valinomycin inhibited hyphal growth and induced growth as a chain of yeast cells under hyphal growth induction conditions in Candida albicans. To elucidate the hyphal growth inhibition by valinomycin, we examined the effect of various chemicals on the morphology and found that miconazole inhibited hyphal growth as well as valinomycin: both compounds promoted the leakage of potassium from cells. Analysis of intracellular potassium suggested that hyphal cells contain potassium at high concentrations in comparison with yeast cells. Hyphal growth inhibition by valinomycin was obstructed by the addition of serum. Potassium measurement showed that the addition of serum causes an increase in intracellular potassium, suggesting that the obstruction by serum might be due to an increase in intracellular potassium. The above-mentioned results strongly suggest that the addition of valinomycin and miconazole decreased interacellular potassium and this decrease inhibited hyphal transition.
\end{abstract}

Keywords Candida albicans, morphology, dimorphism, hyphal growth, potassium, valinomycin, miconazole

\section{Introduction}

Candida albicans is a major opportunistic fungal pathogen that has the ability to switch reversibly between yeast and hyphal forms depending on the environmental conditions

M. Azuma (Corresponding author), H. Watanabe, K. Igarashi, H. Ooshima: Department of Applied Chemistry and Bioengineering, Graduate School of Engineering, Osaka City University, Sugimoto 3-3-138, Sumiyoshi-ku, Osaka 558-8585, Japan, E-mail: azuma@bioa.eng.osaka-cu.ac.jp
[1]. It is thought that this ability is related to pathogenicity, which is reduced by the inhibition of hyphal growth, because morphological mutants defective in hyphal growth exhibit low virulence compared to the parental strain [2]. Understanding the dimorphism and screening for hyphal growth inhibitors should lead to the development of new antifungal therapies.

In a previous report, we described that valinomycin inhibited hyphal growth and induced growth as a chain of yeast cells under hyphal growth induction conditions in $C$. albicans [3]. Valinomycin, a potassium ionophore, is known as an antibiotic against tubercle bacillus, but its effect on the morphology of yeast and fungus is not well known. We also showed that valinomycin inhibited hyphal growth in $C$. tropicalis and Aureobasidium pullulans, which are dimorphic fungi, suggesting that valinomycin is useful for understanding the morphological transition in dimorphic fungi.

The following understanding of hyphal growth inhibition is supposed from the generally known action of valinomycin. Valinomycin may act as an uncoupler of mitochondrial electron transport in C. albicans, cancel the proton gradient in the inner membrane, and inhibit ATP synthesis. A decrease in intracellular ATP leads to a reduction of cAMP in a cell [4]. It is known that dimorphism is controlled via the cAMP-PKA pathways $[5,6]$. The inhibition of hyphal growth by valinomycin may be due to decreased intracellular cAMP. It has been reported that C. albicans ndh51/ndh51 has a defect in ATP synthesis as a result of abnormal electron transport and failed to demonstrate filamentous growth [7]. On the other hand, valinomycin acts as a potassium ionophore, and potassium concentration in a cell may be affected by valinomycin. Potassium is required for various functions in a cell, and intracellular potassium concentration may be related with the morphology of C. albicans.

In this report, to elucidate the mechanism of hyphal 
growth inhibition by valinomycin we examined the effect of various chemicals on the cell morphology and the relationship between intracellular potassium content and cell morphology.

\section{Materials and Methods}

\section{Microorganisms, Media and Culture Conditions}

C. albicans IFO1061 was used in this study. The strain was maintained on YPD agar [1.0\% yeast extract (Difco), 2.0\% polypeptone, $2.0 \%$ glucose and $2.0 \%$ agar]. The cells were precultured in YPD medium at $30^{\circ} \mathrm{C}$ for 24 hours with shaking. For hyphal growth induction, the cells were cultured in SPG medium $[0.17 \%$ yeast nitrogen base without $\left(\mathrm{NH}_{4}\right)_{2} \mathrm{SO}_{4}$ and without amino acids (Difco), $0.1 \%$ L-proline, and 2.0\% D-galactose, $\mathrm{pH} 5.0$ ] or modified Lee's medium [8] [M-Lee; $0.5 \%\left(\mathrm{NH}_{4}\right)_{2} \mathrm{SO}_{4}, 0.02 \%$ $\mathrm{MgSO}_{4} \cdot 7 \mathrm{H}_{2} \mathrm{O}, 0.25 \% \quad \mathrm{~K}_{2} \mathrm{HPO}_{4}, 0.5 \% \mathrm{NaCl}, 1.25 \%$ Dgalactose, $0.05 \%$ L-alanine, $0.13 \%$ L-leucine, $0.1 \%$ Llysine, $0.01 \%$ L-methionine, $0.007 \%$ L-ornithine, $0.05 \%$ Lproline, $0.05 \%$ L-threonine, and $0.0001 \%$ biotin, $\mathrm{pH} 5.0$ ] at $30^{\circ} \mathrm{C}$ for 24 hours. As reported in a previous paper, the ratio of yeast cells in YPD medium was higher than $95 \%$ and the ratios of hyphal cells in SPG and M-Lee media were higher than $90 \%$ [3]. To examine the effect of potassium or sodium concentration in a medium on cell morphology, modified M-Lee (M-M-Lee; M-Lee without $\mathrm{K}_{2} \mathrm{HPO}_{4}$ and $\mathrm{NaCl}$ ) was used and those ions of various concentrations were added to M-M-Lee medium.

\section{Chemicals}

The following chemicals were used to examine the effect on cell morphology: valinomycin (Calbiochem, Schwalbach, Germany), nystatin (Wako Pure Chemical, Osaka, Japan), amphotericin B (Wako Pure Chemical), 5-fluorocytosine, miconazole nitrate (Wako Pure Chemical), 2,4-dinitrophenol (DNP; Nacalai Tesque, Kyoto, Japan), carbonyl cyanide $p$-(trifluoro methoxy) phenylhydrazone (FCCP; Sigma Chemical, St. Louis, MO, USA), bis (12-crown-4) (Dojindo, Kumamoto, Japan), tetrabutylammonium hydrogen sulfate (TBA; ICN Biomedicals, Aurora, OH, USA), lansoprazole (ICN Biomedicals), gramicidin D (ICN Biomedicals), dibutyryl cyclic adenosine monophosphate (dbcAMP, Sigma Chemical), $N$-acetyl-D-glucosamine (GlcNAc, Wako Pure Chemical), and fetal bovine serum (FBS; ICN Biomedicals).

\section{Evaluation of Hyphal Growth Inhibition}

Inhibitory activities for hyphal growth of $C$. albicans were determined by the dilution assay method [3]. Two-fold serial dilutions of chemicals in 11 steps were performed with growth medium in a 96-well plate, and $100 \mu$ of the solutions diluted by 11 steps were prepared in the plate. After subculture in YPD medium, C. albicans cells were harvested, washed twice with $\mathrm{PBS}(0.8 \% \mathrm{NaCl}, 0.02 \%$ $\mathrm{KCl}, 0.02 \% \mathrm{KH}_{2} \mathrm{PO}_{4}$ and $0.29 \% \mathrm{Na}_{2} \mathrm{HPO}_{4} \cdot 12 \mathrm{H}_{2} \mathrm{O}, \mathrm{pH}$ 5.0), and suspended in PBS to an optical density of 0.3 to 0.35 at $600 \mathrm{~nm}$. The cells were diluted 50 times further with the medium. One hundred microliters of the cell suspension was added to $100 \mu \mathrm{l}$ of the solution containing chemicals in a 96-well plate. After 24 hours of incubation, the cell morphology was observed by microscopy.

\section{Measurement of Potassium Concentration}

Analysis of intracellular potassium concentration was carried out as follows. Cells were cultured in $50 \mathrm{ml}$ of YPD, $\mathrm{SPG}, \mathrm{SPG}+10 \%$ serum or M-Lee medium with or without $1.0 \mu \mathrm{g} / \mathrm{ml}$ of valinomycin at $30^{\circ} \mathrm{C}$ for 24 hours with shaking, harvested by centrifugation at $2,300 \mathrm{~g}$ for 15 minutes, washed twice with $0.9 \% \mathrm{NaCl}$, and suspended with $4 \mathrm{ml}$ of $0.9 \% \mathrm{NaCl}$. Generally $20 \mathrm{mM} \mathrm{MgCl}_{2}$ solution was used for washing [9], however we used physiological saline. Five hundred microliters of the cell suspension was used for measurement of the dry cell weight. Glass beads were added to $1.0 \mathrm{ml}$ of the cell suspension, and the cells were vortexed for at least 10 minutes in total. Cell breakage was determined microscopically and the cells $(>95 \%)$ were broken. After removing the cell debris and glass beads by centrifugation of $2,300 \times g$ for 15 minutes, the supernatant was filtered through a $0.45 \mu \mathrm{m}$ filter (ADVANTEC) and used to measure the potassium concentration. Analysis of potassium leakage from cells was carried out as follows. Cells were cultured in $300 \mathrm{ml}$ of YPD medium at $30^{\circ} \mathrm{C}$ for 24 hours with shaking, harvested, washed twice with $0.9 \%$ $\mathrm{NaCl}$, and suspended in $50 \mathrm{ml}$ of $0.9 \% \mathrm{NaCl} .500 \mu \mathrm{l}$ of the cell suspension was used for measurement of the dry cell weight. Two milliliters of $0.9 \% \mathrm{NaCl}$ containing valinomycin or miconazole of various concentrations was added to $2.0 \mathrm{ml}$ of the cell suspension. After 4 hours of incubation, the cells were removed by centrifugation at $2,300 \times g$ for 15 minutes. After the supernatants were diluted appropriately, the potassium concentrations were measured by SAS7500 atomic absorption spectrophotometer (Seiko Instruments Inc.).

\section{Results and Discussion}

\section{Analysis of Hyphal Growth Inhibition by Valinomycin Using dbcAMP and GlcNAc}

As described in the introduction, valinomycin may act as an 
uncoupler of mitochondrial electron transport and affect hyphal growth via the cAMP-PKA pathway. dbcAMP is known to promote hyphal growth in $C$. albicans via the cAMP-PKA pathway [10], and it is also reported that GlcNAc activates the cAMP-PKA pathway and promotes hyphal growth in $C$. albicans $[11,12]$; therefore, the effect of dbcAMP and GlcNAc on hyphal growth inhibition by valinomycin was examined (Table 1). Independent of the addition of dbcAMP and GlcNAc, hyphal growth was inhibited by $1.0 \mu \mathrm{g} / \mathrm{ml}$ of valinomycin. The minimum valinomycin concentration causing hyphal growth inhibition was not affected by those additions (data not shown). These results suggested that the point at which valinomycin acts in hyphal growth inhibition might be downstream of the cAMP-PKA pathway or on an unknown pathway for the induction of hyphal growth.

\section{Effect of Other Factors Causing Hyphal Growth} Induction on Hyphal Growth Inhibition by Valinomycin High temperature $\left(=37^{\circ} \mathrm{C}\right)$, neutral $\mathrm{pH}(=6.5)$ and the addition of serum induced hyphal growth $[1,11,13]$. We examined the effect of these factors on hyphal growth inhibition by valinomycin (Table 1). Environmental factors did not affect the inhibition by valinomycin. On the other hand, the addition of serum obstructed hyphal growth inhibition with $1.0 \mu \mathrm{g} / \mathrm{ml}$ of valinomycin (Fig. 1d), but did not obstruct inhibition with $10 \mu \mathrm{g} / \mathrm{ml}$ of valinomycin (Fig. 1e). However, in medium containing $10 \mu \mathrm{g} / \mathrm{ml}$ of valinomycin, short hyphal cells, which have yeast cells at the tip, were observed in addition to chains of yeast cells. The mechanism for hyphal growth induction by serum is not well known. The action of serum may compete with the action of valinomycin. The details of the relationship between valinomycin and serum in morphological change are described later.

Table 1 Relationship between hyphal growth inhibition by valinomycin and hyphal growth induction by chemicals and environmental factors

\begin{tabular}{lccc}
\hline & \multicolumn{3}{c}{ Cell morphology } \\
\cline { 2 - 4 } $\begin{array}{c}\text { Chemicals and } \\
\text { growth condition }\end{array}$ & \multicolumn{3}{c}{ Valinomycin $(\mu \mathrm{g} / \mathrm{ml})$} \\
\cline { 2 - 4 } & 0 & 1.0 & 10 \\
\hline dbcAMP & Hyphae & Yeast & Yeast \\
GlcNAc & Hyphae & Yeast & Yeast \\
dbcAMP+GlcNAc & Hyphae & Yeast & Yeast \\
Serum & Hyphae & Hyphae & Yeast \\
pH 8.0 & Hyphae & Yeast & Yeast \\
$37^{\circ} \mathrm{C}$ & Hyphae & Yeast & Yeast \\
None & Hyphae & Yeast & Yeast \\
\hline
\end{tabular}

Yeast cells were cultured at $30^{\circ} \mathrm{C}$ for 24 hours in SPG medium $(\mathrm{pH}$ 5.0) with dbcAMP $(0.1 \mathrm{mM})$, GlcNAc $(0.1 \mathrm{mM})$, dbcAMP $(0.1 \mathrm{mM})+$ GIcNAc $(0.1 \mathrm{mM})$ or serum $(10 \%)$. The cells were also cultured at $37^{\circ} \mathrm{C}$ or at $\mathrm{pH}$ 8.0. The morphology of cells cultured in the medium with or without $1.0 \mu \mathrm{g} / \mathrm{ml}$ of valinomycin was observed by microscopy. a

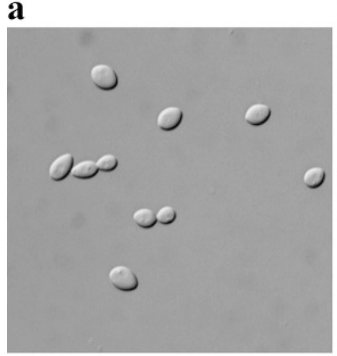

e

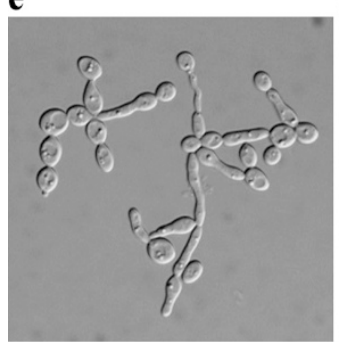

b

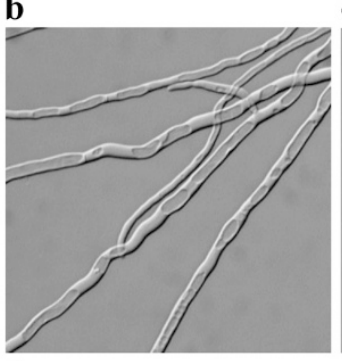

f

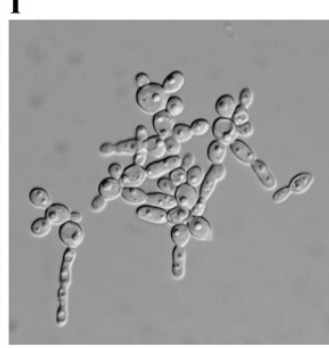

c

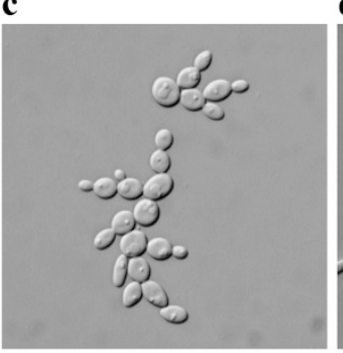

d

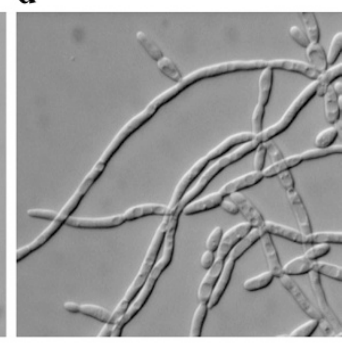

$\mathbf{g}$

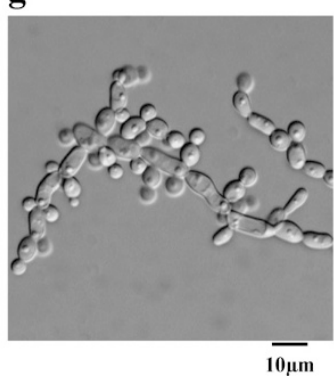

Fig. 1 Morphology of C. albicans cells incubated at $30^{\circ} \mathrm{C}$ for 24 hours.

Used media; YPD (a), SPG (b), SPG $+1.0 \mu \mathrm{g} / \mathrm{ml}$ of valinomycin (c), SPG $+10 \% \mathrm{FBS}+1.0 \mu \mathrm{g} / \mathrm{ml}$ of valinomycin (d), SPG $+10 \%$ FBS $+10 \mu \mathrm{g} / \mathrm{ml}$ of valinomycin (e), SPG $+0.04 \mu \mathrm{g} / \mathrm{ml}$ of miconazole (f), and M-M-Lee (g). 
Table 2 Effects of various chemicals on the cell morphology of C. albicans under hyphal growth conditions (SPG medium)

\begin{tabular}{|c|c|c|c|c|c|c|c|c|c|c|c|c|}
\hline \multirow{2}{*}{ Substance } & \multirow{2}{*}{$\begin{array}{c}\text { Initial } \\
\text { concentration - } \\
(\mu \mathrm{g} / \mathrm{ml})\end{array}$} & \multicolumn{11}{|c|}{ Dilution } \\
\hline & & 1 & 2 & 4 & 8 & 16 & 32 & 64 & 128 & 256 & 512 & 1024 \\
\hline Valinomycin & 100 & $\mathrm{~N}$ & Y & Y & Y & Y & Y & Y & Y & Y & $\mathrm{H}$ & $\mathrm{H}$ \\
\hline \multicolumn{13}{|l|}{ Uncoupler } \\
\hline DNP & 125 & $\mathrm{~N}$ & $\mathrm{~N}$ & Y & Y & Y & $\mathrm{H}$ & $\mathrm{H}$ & $\mathrm{H}$ & $\mathrm{H}$ & $\mathrm{H}$ & $\mathrm{H}$ \\
\hline FCCP & 125 & $\mathrm{~N}$ & $\mathrm{~N}$ & $\mathrm{~N}$ & $\mathrm{~N}$ & Y & Y & Y & Y & $\mathrm{H}$ & $\mathrm{H}$ & $\mathrm{H}$ \\
\hline \multicolumn{13}{|l|}{ Ionophore } \\
\hline Gramicidin D & 100 & $\mathrm{~N}$ & Y & Y & Y & $\mathrm{H}$ & $\mathrm{H}$ & $\mathrm{H}$ & $\mathrm{H}$ & $\mathrm{H}$ & $\mathrm{H}$ & $\mathrm{H}$ \\
\hline Bis(12-crown-4) & 66 & $\mathrm{~N}$ & $\mathrm{~N}$ & Y & Y & $\mathrm{H}$ & $\mathrm{H}$ & $\mathrm{H}$ & $\mathrm{H}$ & $\mathrm{H}$ & $\mathrm{H}$ & $\mathrm{H}$ \\
\hline \multicolumn{13}{|c|}{ Proton pump inhibitor } \\
\hline Lansoprazole & 2.0 & $\mathrm{~N}$ & Y & Y & Y & $\mathrm{H}$ & $\mathrm{H}$ & $\mathrm{H}$ & $\mathrm{H}$ & $\mathrm{H}$ & $\mathrm{H}$ & $\mathrm{H}$ \\
\hline TBA & 2.0 & $\mathrm{~N}$ & Y & Y & Y & $\mathrm{H}$ & $\mathrm{H}$ & $\mathrm{H}$ & $\mathrm{H}$ & $\mathrm{H}$ & $\mathrm{H}$ & $\mathrm{H}$ \\
\hline \multicolumn{13}{|l|}{ Antifungal drug } \\
\hline Nystatin & 10 & $\mathrm{~N}$ & $\mathrm{~N}$ & $\mathrm{~N}$ & $\mathrm{~N}$ & $N$ & $\mathrm{~N}$ & $\mathrm{H}$ & $\mathrm{H}$ & $\mathrm{H}$ & $\mathrm{H}$ & $\mathrm{H}$ \\
\hline Amphotericin B & 1.25 & $\mathrm{~N}$ & $\mathrm{~N}$ & Y & $\mathrm{H}$ & $\mathrm{H}$ & $\mathrm{H}$ & $\mathrm{H}$ & $\mathrm{H}$ & $\mathrm{H}$ & $\mathrm{H}$ & $\mathrm{H}$ \\
\hline 5-Fluorocytosine & 2.0 & $\mathrm{~N}$ & $N$ & $\mathrm{~N}$ & Y & Y & $\mathrm{H}$ & $\mathrm{H}$ & $\mathrm{H}$ & $\mathrm{H}$ & $\mathrm{H}$ & $\mathrm{H}$ \\
\hline Miconazole & 2.0 & $\mathrm{~N}$ & Y & Y & Y & Y & Y & Y & Y & $\mathrm{H}$ & $\mathrm{H}$ & $\mathrm{H}$ \\
\hline
\end{tabular}

Y: chain of yeast cells, $\mathrm{H}$ : hyphae, $\mathrm{N}$ : no growth. Dilution 1 means the initial concentration.

\section{Effects of Various Chemicals on the Cell Morphology of} C. albicans

To investigate the action of valinomycin, the effects of various chemicals on cell morphology were examined (Table 2). Miconazole, an antifungal agent, inhibited hyphal growth of $C$. albicans over a wide range of concentrations $(0.0156$ to $1.0 \mu \mathrm{g} / \mathrm{ml})$ as well as valinomycin, and induced growth as a chain of yeast cells (Fig. 1f). In addition, miconazole inhibited hyphal growth at lower concentrations than valinomycin. Odds et al. have reported that miconazole suppressed emergence of new hyphal outgrowths from yeast cells [14]. Miconazole is known to inhibit the biosynthesis of ergosterol, which is a fungal cell membrane component. As a result of biosynthesis inhibition by miconazole, membrane permeability is changed and positive ions leak from a cell $[15,16]$. Our result accords with this report. It is suggested that valinomycin, a potassium ionophore, and miconazole are both involved in the leakage of potassium from cells of $C$. albicans and that the change of intracellular potassium concentration may cause hyphal growth inhibition. Gramicidin D is also known as a cationchannel ionophore, but did not inhibit hyphal growth over a wide range of concentrations as observed with valinomycin (Table 1). Gramicidin D and valinomycin transport cations with one positive charge (potassium, sodium, hydrogen etc.) and potassium, respectively. The difference in the effective concentration may be due to that gramicidin D transport several cations with one positive charge and the transport of cations except potassium disturbs the hyphal growth inhibition by the potassium transport.

\section{Potassium Leakage from a Cell by the Addition of Valinomycin or Miconazole}

We examined the leakage of potassium from cells by the addition of valinomycin or miconazole. Yeast cells suspended in $0.9 \% \mathrm{NaCl}$ solution containing valinomycin or miconazole at various concentrations were incubated for 4 hours and the potassium content of the supernatant after centrifugation was measured (Fig. 2). Potassium leaked from cells in the solution without additions, and the addition of valinomycin and miconazole increased potassium leakage to 1.9 and 1.4 times compared to without addition, respectively. These results suggest that the addition of valinomycin or miconazole affects the intracellular potassium content of $C$. albicans.

\section{Effect of Potassium Concentration in Growth Medium on Cell Morphology of $\boldsymbol{C}$. albicans}

We examined the effect of potassium concentration in growth medium on cell morphology (Table 3 ). In medium (M-M-Lee) with valinomycin, cells grew as a chain of yeast cells, independent of the potassium concentration. On the other hand, in medium without valinomycin, the addition of up to $0.049 \mu \mathrm{M}$ potassium led to growth as a 
chain of yeast cells (Fig. 1g), and the addition of $0.098 \mu \mathrm{M}$ or greater potassium led to growth as hyphae. This tendency was not influenced by the addition of $100 \mathrm{mM}$ $\mathrm{NaCl}$. These results suggest that potassium in the growth medium is necessary for hyphal growth. It is possible that valinomycin affects cell morphology via a change in intracellular potassium concentration.

\section{Relationship between Cell Morphology and Intracellular Potassium Concentration}

To elucidate the relationship between intracellular potassium concentration and cell morphology, the potassium content

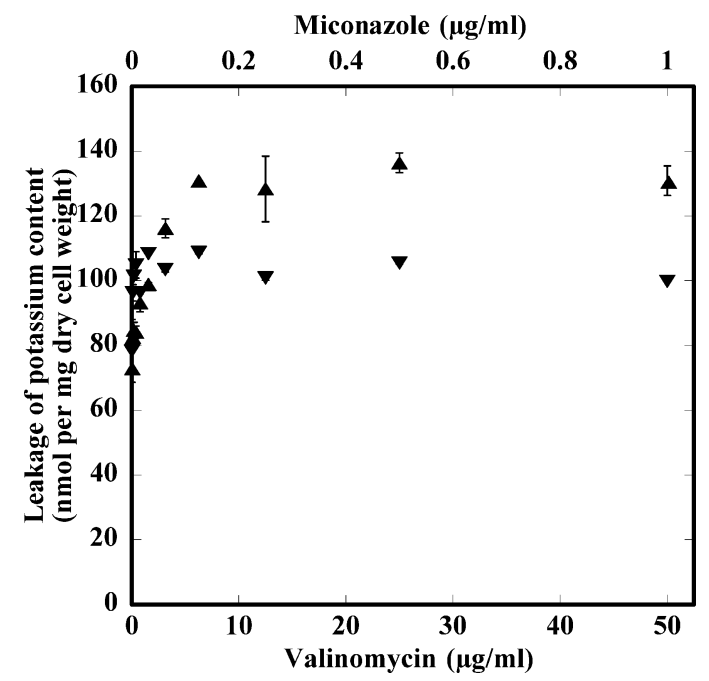

Fig. 2 Potassium leakage from a cell by the addition of valinomycin or miconazole.

Yeast cells cultured in YPD medium at $30^{\circ} \mathrm{C}$ for 24 hours were exposed to $0.9 \% \mathrm{NaCl}$ containing valinomycin (closed triangle) or miconazole (closed reverse-triangle) for 4 hours and the potassium leakage was measured. Each value represents the average of three independent assays \pm S.D. of cells grown in various media was measured (Fig. 3). Almost all cells cultured in SPG and M-Lee media grew in hyphal form and the potassium content was approximately $1050 \mathrm{nmol}$ per mg dry cell weight. On the other hand, almost all cells cultured in YPD both with and without valinomycin grew in yeast form, and the content was approximately $600 \mathrm{nmol}$ per mg dry cell weight. Almost all cells cultured in SPG and M-Lee with valinomycin grew as a chain of yeast cells and the potassium content was 520 and $560 \mathrm{nmol}$ per mg dry cell weight, respectively. The potassium content of chained yeast cells cultured in SPG with miconazole and gramicidin D was almost identical to the content of cells cultured in SPG with valinomycin, MLee with valinomycin and YPD. The potassium content in chained yeast cells cultured in M-M-Lee without potassium was lowest of all, and the value was $260 \mathrm{nmol}$ per mg dry cell weight. These results suggest that the potassium content in hyphal cells was higher than that in yeast cells, including chained yeast cells.

Next, we examined the time course of intracellular potassium concentration and ratio of hyphal cells after transfer between different growth media (Fig. 4). In cells transferred to SPG without valinomycin from YPD, the potassium content and ratio of hyphal cells increased with time. On the other hand, in cells transferred to SPG with valinomycin, the potassium content and ratio of hyphal cells did not increase with time. These results suggest that increased intracellular potassium concentration may be necessary for the transition from yeast to hyphal form.

\section{Effect of Serum and Valinomycin on Intracellular Potassium Content}

As shown in Table 1, hyphal growth inhibition with $1.0 \mu \mathrm{g} / \mathrm{ml}$ of valinomycin was obstructed by the addition of serum; therefore, the effect of serum on intracellular

Table 3 Effect of potassium concentration in the medium on the cell morphology of C. albicans

\begin{tabular}{|c|c|c|c|c|c|c|c|c|c|c|}
\hline \multirow{3}{*}{$\begin{array}{l}\mathrm{NaCl} \\
(\mathrm{mM})\end{array}$} & \multirow{3}{*}{$\begin{array}{l}\text { Valinomycin } \\
\qquad(\mu \mathrm{g} / \mathrm{ml})\end{array}$} & \multicolumn{9}{|c|}{$\mathrm{KCl}$} \\
\hline & & \multicolumn{6}{|c|}{$(\mu \mathrm{M})$} & \multicolumn{3}{|c|}{ (M) } \\
\hline & & 0 & 0.02 & 0.049 & 0.098 & 0.2 & 0.39 & 0.5 & 1.0 & 2.0 \\
\hline \multirow[t]{2}{*}{100} & 1.0 & $Y$ & $Y$ & $Y$ & $Y$ & $Y$ & $Y$ & $Y$ & $Y$ & $\mathrm{~N}$ \\
\hline & 0 & Y & $Y$ & $Y$ & $\mathrm{H}$ & $\mathrm{H}$ & $\mathrm{H}$ & $\mathrm{H}$ & $\mathrm{H}$ & $\mathrm{N}$ \\
\hline \multirow[t]{2}{*}{0} & 1.0 & $Y$ & $Y$ & $Y$ & $Y$ & $Y$ & $Y$ & $Y$ & $Y$ & $\mathrm{~N}$ \\
\hline & 0 & $Y$ & $Y$ & $Y$ & $\mathrm{H}$ & $\mathrm{H}$ & $\mathrm{H}$ & $\mathrm{H}$ & $\mathrm{H}$ & $N$ \\
\hline
\end{tabular}

Y: chain of yeast cells, $\mathrm{H}$ : hyphae, $\mathrm{N}$ : no growth. Yeast cells grown in YPD medium were incubated in M-M-Lee medium containing the indicated concentration of $\mathrm{NaCl}$ and $\mathrm{KCl}$ with or without $1.0 \mu \mathrm{g} / \mathrm{ml}$ of valinomycin at $30^{\circ} \mathrm{C}$ for 24 hours. The cell morphology was observed by microscopy. 


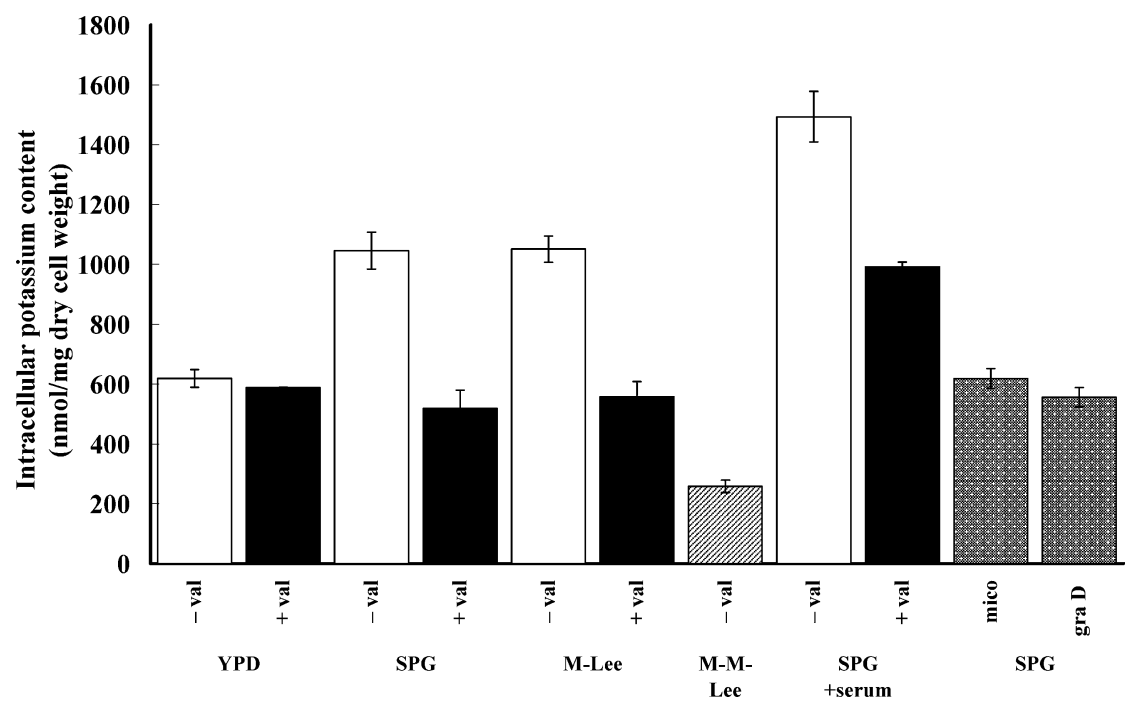

Fig. 3 Intracellular potassium content in cells grown in various media.

Yeast cells subcultured in YPD medium were cultured in each medium at $30^{\circ} \mathrm{C}$ for 24 hours, and the intracellular potassium content was determined. + val, mico, and gra $\mathrm{D}$ indicate the addition of $1.0 \mu \mathrm{g} / \mathrm{ml}$ of valinomycin, $0.04 \mu \mathrm{g} / \mathrm{ml}$ of miconazole, and $10 \mu \mathrm{g} / \mathrm{ml}$ of gramicidin D, respectively. Each value represents the average of three independent assays \pm S.D.

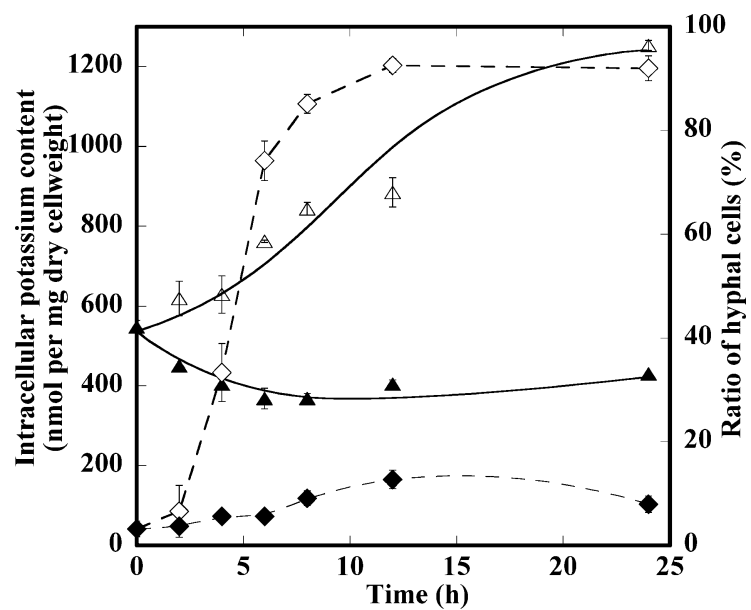

Fig. 4 Time course of intracellular potassium content and ratio of hyphal cells.

Yeast cells subcultured in YPD medium were cultured in SPG medium with or without $1.0 \mu \mathrm{g} / \mathrm{ml}$ of valinomyin at $30^{\circ} \mathrm{C}$ with shaking. Closed and open triangles indicate potassium content in cells grown with and without valinomycin, respectively. Closed and open diamonds indicate hyphal cell ratios in cells grown with and without valinomycin, respectively. Each value represents the average of three independent assays \pm S.D.

potassium concentration was examined. The results are shown in Fig. 3. Cells cultured in SPG with and without serum grew in hyphal form, and the potassium content in cells grown in SPG with serum was higher than that in SPG without serum. In SPG medium containing $1.0 \mu \mathrm{g} / \mathrm{ml}$ of valinomycin, the addition of serum inhibited growth as a chain of yeast cells. The potassium content in cells grown in SPG with serum was higher than that in SPG without serum, and the value was almost the same as that in SPG without both valinomycin and serum. These results suggest that the addition of serum increased intracellular potassium and as a result, hyphal growth is induced.

In conclusion, we investigated the mechanism of hyphal growth inhibition by valinomycin and miconazole. The results obtained suggest that the addition of valinomycin and miconazole leads to a decrease in intracellular potassium concentration, and this decrease inhibits the transition to hyphal form. The addition of serum may induce hyphal growth via an increase in intracellular potassium concentration. Intracellular potassium must play a very important role in this dimorphism.

\section{References}

1. Shepherd MG, Yin CY, Ram SP, Sullivan PA. Germ tube induction in Candida albicans. Can J Microbiol 26: 21-26 (1980)

2. Diez-Orejas R, Molero G, Ríos-Serrano I, Vázquez A, Gil C, Nombela C, Sánchez-Pérez M. Low virulence of a morphological Candida albicans mutant. FEMS Microbiol Lett 176: 311-319 (1999)

3. Watanabe $\mathrm{H}$, Azuma $\mathrm{M}$, Igarashi $\mathrm{K}$, Ooshima $\mathrm{H}$. Valinomycin affects the morphology of Candida albicans. J Antibiot 58: 753-758 (2005) 
4. Ueno Y, Fukumatsu M, Ogasawara A, Watanabe T, Mikami T, Matsumoto T. Hyphal formation of Candida albicans is regulated by polyamines. Biol Pharm Bull 27: 890-892 (2004)

5. Liu H. Transcriptional control of dimorphism in Candida albicans. Curr Opin Microbiol 4: 728-735 (2001)

6. Sabie FT, Gadd GM. Effect of nucleosides and nucleotides and the relationship between cellular adenosine $3^{\prime}: 5^{\prime}$-cyclic monophosphate (cyclic AMP) and germ tube formation in Candida albicans. Mycopathologia 119: 147-156 (1992)

7. Justin AM, Vasker B, Tania S, Margaret KH. Involvement of Candida albicans NADH dehydrogenase complex I in filamentation. Fug Genet Biol 36: 117-127 (2002)

8. Lee KL, Buckley HR, Campbell CC. An amino acid liquid synthetic medium for the development of mycelial and yeast forms of Candida albicans. Sabourauddia 13: 148-153 (1975)

9. Kinclová O, Potier S, Sychrová H. Difference in substrate specificity divides the yeast alkali-metal-cation $/ \mathrm{H}^{+}$ antiporters into two subfamilies. Microbiol 148: 1225-1232 (2002)

10. Niimi M. Dibutyryl cyclic AMP-enhanced germ tube formation in exponentially growing Candida albicans cells.
Fung Gent Biol 20: 79-83 (1996)

11. Mattaia E, Carruba G, Angiolella L, Cassone A. Induction of germ tube formation by $N$-acetyl-D-glucosamine in Candida albicans: uptake of inducer and germinative response. J Bacteriol 152: 555-562 (1982)

12. Castilla R, Passeron S, Cantore ML. N-Acetyl-Dglucosamine induces germination in Candida albicans through a mechanism sensitive to inhibitors of cAMPdependent protein kinase. Cell Signal 10: 713-719 (1998)

13. Pollack JH, Hashimoto T. The role of glucose in the $\mathrm{pH}$ regulation of germ-tube formation in Candida albicans. J Gen Microbiol 133: 415-424 (1987)

14. Odds FC, Cockayne A, Hayward J, Abbott AB. Effects of imidazole- and triazole-derivative antifungal compounds on the growth and morphological development of Candida albicans hyphae. J Gen Microbiol 131: 2581-2589 (1985)

15. Cope JC. Mode of miconazole on Candida albicans: effect on growth, viability and $\mathrm{K}^{+}$release. J Gen Microbiol 119: 245-251 (1980)

16. Beggs HW. Direct membrane damage and miconazole lethality. Res Commun Chem Pathol Pharmacol 77: 249-252 (1992) 